\title{
One strategy at work for more than 260 reasons
}

\author{
by J eff Young ${ }^{1}$
}

\begin{abstract}
Canadians are taking action to advance sustainable forest management with the National Forest Strategy (NFS) 2003-2008, A Sustainable Forest: The Canadian Commitment. This national policy framework reaffirms Canadians' long-term vision and defines strategic targets to be achieved by the forest community at large. Seen as an international model, the NFS serves to establish partnerships and to promote policies as encouraged by the Final Statement issued at the XII World Forestry Congress. Canada and the United States of America have national forest programmes that are advancing a sustainable N orth American forest and are contributing to the well-being of the global forest. Stronger mechanisms and liaisons between developed countries with such programmes will help Canada and other likeminded countries to push sustainable forest management concepts even further as they evolve.
\end{abstract}

Key words: global forest convention, international network, national forest programme, National Forest Strategy Coalition, sector roundtable

\section{RÉSUMÉ}

Les Canadiens prennent les moyens pour faire progresser l'aménagement forestier durable avec la Stratégie nationale sur la forêt (SNF) 2003-2008, Une Forêt durable : L'engagement canadien. Ce cadre de référence national réaffirme la vision à long terme des Canadiens et définit les objectifs stratégiques à atteindre par l'ensemble de la collectivité forestière. Perçue comme un modèle international, la SNF sert à établir des partenariats et à promouvoir des politiques comme l'a soutenu la Déclaration finale émise lors du XII ${ }^{e}$ Congrès forestier mondial. Le Canada et les Etats-Unis d'Amérique ont mis en place des programmes forestiers nationaux qui mettent en relief une forêt nord-américaine durable et contribuent au mieux-être des forêts mondiales. Des mécanismes et des liens plus solides entre les pays développés ayant de tels programmes aideront le Canada et les autres pays alignés sur la même vision à pousser encore plus à l'avant les concepts d'aménagement forestier durable à mesure de leur développement.

Mots clés : congrès forestier mondial, réseau international, programme forestier national, Coalition pour la Stratégie nationale sur la forêt, table ronde sectorielle

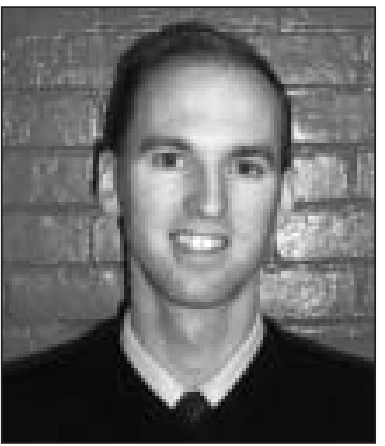

J eff Young

\section{Introduction}

In several countries around the world, national forest programmes are stimulating productive partnerships for responsible forest management. They engage people who care about using and conserving the forest that defines their home and nation. These programmes are constantly evolving in ways that help define what it means to achieve a sustainable forest, for all types of forest.

In effect, there are 260 reasons to put national forest programmes to work. These reasons correspond to the number of countries around the world that benefit from the forest and the ongoing stewardship efforts that sustain it. Other reasons for conducting national forest programmes are to address priority issues concerning the forest and delivering on promises that will fulfill national and international responsibilities.

\footnotetext{
${ }_{1} \mathrm{M}$ ember of the Canadian Institute of Forestry/Institut forestier du Canada; Secretariat to the National Forest Strategy Coalition, Ottawa, Ontario. E-mail: jeyoung@nrcan.gc.ca
}

\section{The Makings of National Forest Programmes in Canada and the United States}

North Americans are in a global economy and manage nearly a fifth of the world's forest (CFS 2004a, USDA 2002). They have made international commitments to its conservation. To fulfill these commitments and others, Canada and the United States have policies and coordinated initiatives that amount to national forest programmes. These programmes are suited to the collaborative arrangements in each country. The way these two programmes continue to evolve demonstrates a tradition of consensus-building north of the shared border and a transition to fewer legal disputes south of it (Douglas 2004, Scardina and M ortimer 2004). The Canadian and the United States programmes share mission statements that are consistent with the Forest Principles of the 1992 United Nations Conference on Environment and Development (UNCED).

The mission statement of the United States is:

"To sustain the health, diversity and productivity of the nation's forests and grasslands to meet the needs of present and future generations."

This mission statement is conveyed through several policy documents (USDA 2002). Pursuing the mission statement involves federal legislation, state regulation, and private landowner responsibility. 


\section{The vision in Canada is:}

"The long-term health of Canada's forest will be maintained and enhanced, for the benefit of all living things, and for the social, cultural, environmental and economic well-being of all Canadians, now and in the future."

While sustainable forest management in Canada is also driven by many governmental and non-governmental policies and programs, the Canadian vision is primarily conveyed through a single framework for action the National Forest Strategy (NFS) 2003-2008, A Sustainable Forest: The Canadian Commitment. This is Canada's fifth national forest programme. It has constantly been evolving and bringing the forest community together for over 20 years (NFSC 2003a).

For good reason, Canada's N FS stands out as an international model for consensus-building in sustainable forest management. N ot only was its development led by a diverse governmental and non- governmental partnership, but the process also involved extensive cross-country consultations and public dialogue within the forest community and forestrelated communities. The result is an NFS that contains eight strategic themes and 47 action items to be delivered by everyone with an interest in the forest. The incentives for making the NFS work are to address priority issues concerning the forest, to deliver on promises, and to demonstrate global leadership. These are also reasons for making national forest programmes work in other countries.

\section{Addressing Priority Issues}

The implementation of Canada's N FS is a significant example of how Canadians address priority issues. These issues include wildfire risks, exotic and invasive pest infestations, habitat and species loss, science and technology challenges, market pressures, and community concerns (CFS 2004b). The United States faces similar issues (USDA 2002).

A national forest programme that integrates environmental, economic and social objectives also positions the forest sector strategically relative to competing sectors and within broader public agendas. For example, during his September 10, 2004 presentation to the Calgary Chamber of Commerce, the Honourable Stéphane Dion, federal $M$ inister of the Environment, called for a new environmental framework to introduce strong investments in sustainable practices and give Canadian industries a competitive advantage in the global economy. Such a framework would integrate long-term economic and environmental objectives, and include "sector sustainability roundtables," to bring partners together, chart the course through sectorial strategies, and achieve environmental targets.

Forward thinking gave Canada its first national forest sector strategy in 1981, at that time under Environment Canada's leadership (N FSC 2003b). Since then, the partnership approach for implementing the current NFS has come a long way. The NFS has proven to work well in building momentum and leveraging resources for action. A few examples of priority issues, aligned with the NFS and where progress is being made, are presented in Table 1.

The National Forest Strategy Coalition (NFSC), which monitors and reports on these efforts and asks a third party to evaluate progress, is truly a roundtable that delivers. The NFSC brings together diverse individuals, companies and organizations who agree to work cooperatively on NFS actions. As of O ctober 2004, 67 national and regional champions are part of this ever-expanding Canada-wide governmental and non-governmental partnership. Members set clear targets, take actions and communicate results. Others are also implementing sustainable forest management activities that relate to the NFS. They, too, can join and add benefit to the exercise, and gain from it, by sharing their experiences.

The governmental members of the NFSC belong to the Canadian Council of Forest Ministers (CCFM; http:// ccfm.org), which consists of the governing elected officials of all Canadian federal and provincial forest jurisdictions. They committed to addressing national and international issues and setting the overall direction for stewardship and sustainable management of Canada's forest. Here, too, these governments appreciate the value of working together as a group, as well as in partnership with the forest community at large. Progress in implementing the NFS is reported to the CCFM .

\section{Delivering on Promises}

The ability to deliver on the ambitious objectives stated in the NFS requires a high level of commitment and support by many to achieve results. While parts of the forest community may at times question the sincerity and capacity to deliver, others commend the commitment and have joined in to participate (Sierra Club of Canada 2003).

Bringing the forest sector together through the Canada Forest Accord is a notable achievement in itself. The Accord is signed by forest ministers, several industry leaders, and many non-governmental organizations. The signatories are essentially promising to actively work toward a sustainable forest (NFSC 2003c).

Another noteworthy action is the CCFM's National Forest Information System (http://nfis.org), which provides the most comprehensive information available on Canada's forest ecosystems. This achievement responds to NFS action item 8.3, which calls for creating a publicly accessible forest information system. Many more actions, of course, are being taken and will be communicated over the NFS implementation period, which extends to M ay 2008.

As do their United States counterparts, the Canadian Institute of Forestry/Institut forestier du Canada and Natural Resources Canada's Canadian Forest Service continue to deliver national forest programme activities in ways that are relevant to their respective mandates and capabilities. Here is how these two organizations are moving forward to implement the NFS:

- The Canadian Institute of Forestry/Institut forestier du Canada, a non-governmental organization, is delivering NFS actions through its national and regional program of activities and its cross-country partnerships. Some efforts aim to enhance the skills and knowledge of forest practitioners, support continuing education and technology transfer, and raise forestry awareness. Other actions aim to improve how forest-reliant communities and private wood lot owners respond to forestry challenges.

- Natural Resources Canada's Canadian Forest Service is developing a federal implementation response that 
Table 1. Examples of priority issues, aligned with the NFS, where progress is being made

\begin{tabular}{lll}
\hline Priority issue & NFS theme & Examples of progress \\
\hline Pressures in the boreal forest region & 1) Ecosystem-based management & $\begin{array}{l}\text { Protected areas continue to increase steadily } \\
\text { through provincial and territorial science- } \\
\text { based strategies, efforts of non-governmental } \\
\text { organizations, the national parks system, } \\
\text { and conservation occurring outside formally } \\
\text { protected areas. }\end{array}$ \\
\hline
\end{tabular}

Exotic and invasive pests

1) Ecosystem-based management

5) Knowledge and innovation for competitiveness and sustainability

8) Reporting and accountability
A national invasive alien species strategy ${ }^{1}$ has been developed to preserve wildlife, fish and forest habitat from exotic and invasive pests. The strategy focusses on prevention, detection, response and recovery in both urban and rural areas.
Wildfires and community safety
1) Ecosystem-based management
2) Sustainable forest communities
3) Rights and participation of Aboriginal peoples
4) Forest products benefits
5) Knowledge and innovation for competitiveness and sustainability
8) Reporting and accountability

A national forest fire program is being developed to protect people and communities from an increasing risk of wildfire (NRCanCFS 2004b). The plan will aim to reduce wildfire risks, while preparing for the eventuality of wildfire by providing the capacity to respond and recover.
Competitiveness, market access and product diversification
4) Forest products benefits

5) Knowledge and innovation for competitiveness and sustainability
The Canadian Forest Innovation Council2 coordinates research and development efforts among government and industry. As a result, new ways to increase competitiveness, market access, and product diversification are being used.

\footnotetext{
1 http://www.scics.gc.ca/cinfo04/830820001_e.html

2 http://www.innovation.gc.ca/gol/innovation/site.nsf/en/in04841.html
}

encompasses a majority of the action items in the NFS and involves some 20 federal departments and agencies. The response will demonstrate the federal government's actions to advance sustainable forest management across Canada in partnership with others in the forest community and other sectors. It will also illustrate the vital role the forest plays in Canada, and the steps being taken to fulfill international forest-related responsibilities.

\section{Demonstrating Global Leadership}

Canada was instrumental in pioneering the sustainable forest management concept and was among the first to develop a national forest programme. Well before UNCED tied forest use to what is now known as sustainable forest management, Canada was developing consensus and collaborative approaches to improve its forest practices. In the 1980s, Canada developed two national forest strategies to guide its forest community actions. During this time, a Canadian directed the Brundtland Commission, and several hearings were held in Canada that led to the influential Brundtland Report, Our Common Future (Webster 1998). The report emphasized sustainable development. To demonstrate this concept through a national forest programme and generate further international interest, Canada featured its 1992 N FS at UNCED.

Based on its experience, Canada took a lead role in the international call for national forest programmes. Canadians also gave themselves the NFS to meet both national and international responsibilities. By design, the NFS objectives align with the World Summit on Sustainable Development, encompass the forest-related commitments under the UNCED - Forest Principles, and embody parts of the Montréal Process - Criteria and Indicators of Sustainable M anagement of Temperate and Boreal Forests. The NFS also addresses related international commitments under the Convention on Biological Diversity, the Framework Convention on Climate Change, and its Kyoto Protocol, and the Convention on the International Trade in Endangered Species of Wild Fauna and Flora (CITES).

The NFS supports Canada's international reporting, and is showcased abroad as a model that demonstrates sustainable forest management in action. For example, it was featured at the XII World Forestry Congress (Canada, September 2003). The Congress concluded with a Final Statement calling for partnerships and policies such as those introduced by national forest programmes (FAO 2003). Clearly, activities that relate to the N FS and pursue the Final Statement are important to the world's forest and the life it sustains. Canada's leadership in sustainable forest management can be reaffirmed through NFS actions, in timefor the XIII World Forestry Congress, anticipated in 2009.

Canada continues to be in favour of a holistic, legally binding, international forest agreement for all types of forest. A global forest convention that sets targets through 
internationally agreed-upon measures would bring accountability and a stronger definition of what it means to implement sustainable forest management, for example through national forest programmes (Humphreys 2004). This is all the more reason for Canadians to demonstrate sustainable forest management activities through the NFS.

\section{Sharing Experiences and M oving Forward}

Putting a national forest programme to work by bringing diverse organizations together is a proven way to make a difference in sustainable forest management in Canada. Canada's N FS continues to evolve, just as national forest programmes are evolving in the United States and elsewhere.

Canada and United States cooperate strongly to address a wide array of individual issues (for example, wildlife, wildfires and pollution). Given the similar values, strong trade relations, and comparable governance structures, it would seem reasonable for both countries to exchange views on ways that might advance national forest programmes. In doing so, both countries could move even closer to the conservation and wise use of the North American forest. Conceptually, the structure might resemble that used by the 44 European states that gather to discuss forest protection in Europe ( $M$ inisterial Conference on the Protection of Forests in Europe; http://www.mcpfe.org). Canada could consider raising this opportunity through the Food and Agriculture Organization's (FAO) North American Forestry Commission, which it chairs until 2007. A good start might be to approach the United States to jointly develop a mechanism for cooperation and to invite them, as observers, to attend a NFSC meeting.

Just as developing countries have an intergovernmental dialogue on national forest programmes, through the FAO's National Forest ProgrammeFacility, a network is needed for developed countries that are not part of an existing process. This would strengthen the dialogue between national forest programme secretariats in developed countries and would help Canada and other like minded countries to push sustai nable forest management concepts and approaches even further than is currently possible. In order to facilitate this dialogue, there appear to be two options. The preferred option is that the FAO could broaden the focus of the National Forest Programme Facility in a way that supports knowledge-sharing among national forest programme secretariats in developed countries. The second option is that Canada, as a member of the FAO Committee on Forestry, could recommend that the FAO set up a liaison group for developed countries with national forest programme secretariats so they can more easily talk about how they do their work. A side event at the Committee's M arch 2005 meeting (or in spring 2007) could provide an opportunity for Canada's N FSC to present this idea.

Canada is open to sharing its experiences and to learning from the United States and the other countries around the world so that improvements can be made to the way future sustainable forest management strategies are developed, implemented and evaluated. To learn more about the NFS and why it is a strategy that will continue to serve as a model for Canadians well into the future, please visit the NFSC Web site: http://nfsc.forest.ca.

\section{References}

Natural Resources Canada - Canadian Forest Service (CFS), 2004a. Canada's National Forest Inventory. Victoria, BC. Available on the Internet at http://www.pfc.cfs.nrcan.gc.ca/monitoring/ inventory/canfi/facts_e.html

Natural Resources Canada - Canadian Forest Service (CFS). 2004b. The State of Canada's Forests 2003-2004 Fourteenth Report to Parliament. Ottawa, ON. 94 p. Available on the Internet at http://www.nrcan-rncan.gc.ca/cfs-scf/national/what-quoi/sof/ latest_e.html

Douḡlas, T. 2004. National Forest Strategy and Canada Forest Accord Turn Potential Enemies Into Across-The-Table Dialoguers. Evergreen M agazine (Fall 2004): 11-14.

Food and Agriculture Organization of the United Nations (FAO). 2003. XII World Forestry Congress Final Statement: Forests, source of life. FAO, Rome. Available on the Internet at http://www.fao.org/ docrep/article/wfc/xii/finalstat-e.htm

Humphreys, D. 2004. National Forest Programmes as Policy Vehicles for Sustainable Forest Management: Findings from a Major Pan-European Research Project (COST action E19). 8 p.

National Forest Strategy Coalition (NFSC). 2003a. National Forest Strategy (2003-2008), A Sustainable Forest: The Canadian Commitment. Ottawa, ON. 26 p. Available on the Internet at http://nfsc.forest.ca/strategies/strategy5.html

National Forest Strategy Coalition (NFSC). 2003b. People and Forests in Harmony - Evolution of Canada's National Forest Strategy. Paper no. 0560-C2. In Proceedings of the XII World Forestry Congress, QuĖbec City, Canada, September 21-28, 2003. Available on the Internet at http://www.fao.org/docrep/article/ wfc/xii/0560-c2.htm

National Forest Strategy Coalition (NFSC). 2003c. Canada Forest Accord. Ottawa, ON. 1 p. Available on the Internet at http:// nfsc.forest.ca/accord e.htm

Scardina, A.V. and M.J. Mortimer. 2004. Integrating Legal Conflicts into U.S. Public Forest Policy Analysis: A Shift in Paradigm. Virginia Tech Department of Forestry, Blacksburg. 6 p.

Sierra Club of Canada. 2003. Will the National Forest Strategy Make a Difference? A Sierra Club of Canada Assessment. Ottawa: Sierra Club of Canada $13 \mathrm{p}$. Available on the Internet at http://www.sierraclub.ca/national/programs/biodiversity/forests/s cc-fs-response.pdf

United States Department of Agriculture Forest Service (USDA). 2002. Johannesburg Summit 2002. United States of America Country Profile. World Summit on Sustainable Development, August 26 to September 4, 2002. New York: United Nations Department for Economic and Social Development . Available on the Internet at http://www.un.org/esa/agenda21/natlinfo/wssd/ usa.pdf

Webster, H. 1998. Some Comparisons of Canadian and U.S. Attitudes/Behaviour Concerning Sustainable Development. Canadian Review of American Studies 28(1): 1-18. 